\title{
The Journal of Glaciology: its origin and early history
}

\author{
John W. GLEN \\ 166 Sellywood Road, Bournville, Birmingham B30 1UX, UK \\ E-mail: john_glen@jgla.demon.co.uk
}

\begin{abstract}
This paper records the history of how and why the Journal of Glaciology was started and how it has grown into the Journal we know today.
\end{abstract}

Before the Second World War the leading periodical publishing papers on glacier science had been the Zeitschrift für Gletscherkunde, while the main international meetings where glaciology was discussed were meetings of the International Commission on Snow (ICS), part of the International Association of Scientific Hydrology, itself part of the International Union of Geodesy and Geophysics. After the war the editor of the Zeitschrift, R. von Klebelsberg, had no contacts with anyone and the publishing of scientific journals in Germany and Austria was in disarray. In England, Gerald Seligman felt that there was a need for some means of publication to resume. He was himself editor of Ski Notes and Queries and had, before the war, at the suggestion of Dr J.E. Church, the President of ICS, convened meetings of British members of ICS in what was termed the Association for the Study of Snow and Ice (ASSI). Indeed this body had published its Papers and Discussions in duplicated typescript form in 1939; I possess the last of these ever issued, Vol. 1, No. 3. Gerald Seligman was an accomplished amateur skier and had also published Snow structures and ski fields, a major work on snow science. He was thus in a position to advance this project and he changed ASSI into the British Glaciological Society and in January 1947 issued the first number of the Journal of Glaciology. The cover lists the Editorial Committee as Gerald Seligman, Launcelot Fleming, Brian Roberts and Robert Moss. Launcelot Fleming was a geologist and also an Anglican priest. At Sir Vivian Fuchs's suggestion he had been on an expedition to study Vatnajökull in Iceland led by Brian Roberts in 1932 and also on an expedition to study the Ny Friesland ice cap in Svalbard led by A.R. Glen (no relation). He had also been a member of the British Graham Land Expedition 1934-37, the first major British expedition since Scott's last journey in 1911. He was also active in ASSI, as its publications record. He was subsequently Dean of Trinity Hall in Cambridge and Bishop of Portsmouth. Brian Roberts subsequently worked with the Foreign and Commonwealth Office on Antarctic affairs.

Initially the Journal of Glaciology was published twice a year, and the first volume consists of ten issues, i.e. five years. The first issue (see Fig. 1 for the contents page) carries a foreword by $\mathrm{H}$. W:son Ahlmann, the eminent Swedish glaciologist, and the second issue another by François $\mathrm{E}$. Matthes from the United States (reproduced in this issue, p. vii). The second issue also contained an article under the heading 'Instruments and Methods', and a note under this heading invited further contributions to this section, and this heading still continues. In the third issue the first of a series of annual reports of the Snow Survey of Great Britain is included, that for 1946-47, and this issue also contained the first article with its abstract also followed by a German translation, and from then on most articles carried either a
German or French translation of their abstracts. This continued until No. 26 when both French and German abstracts were published for each original paper. From No. 4 Gerald Seligman is listed as Editor (which he always was of course). By No. 7, the Advisory Committee is enlarged by the addition of Sid E. Hollingworth, Doris Johnson, W. Vaughan Lewis and Gordon Manley while Launcelot Fleming is dropped. Sid Hollingworth, Professor of Geology at University College London, had been active in advising on the start of the Society, Doris Johnson, a former librarian at the Scott Polar Research Institute, remained active on the Journal for many years principally in compiling the Glaciological Literature section, Vaughan Lewis lectured in geography at Cambridge University and was later a VicePresident and Chairman of the Committee of the British Glaciological Society, and Gordon Manley was Professor of Geography at Bedford College, University of London.

I joined the Advisory Committee in 1953 and from then on was involved in editing papers. By this time Gerald Seligman had moved from London to an old house in Kent known as Little Dane and he devoted its attic to the Journal. He had a number of trestle tables on which to work and it was there that we discussed papers that had been submitted. Editing was a very complete activity: not only did the editor deal with refereeing of manuscripts, but also with the preparation of the manuscript with full instructions for the printer, from whom in due course we received galley proofs which were sent to authors and then corrections were returned to the printers and Gerald would paste up the galleys to indicate the pagination of the issue. Page proofs would then come back and be read and corrected before the whole was finally sent off to the printers for printing, binding and distribution. As there were only two issues a year, there was an appreciable gap between working on one issue and the next. A lot of the work was of course done by correspondence and I was in almost daily contact with Gerald while an issue was being prepared. By 1955 the difference between the work I was doing and that being done by other members of the Advisory Board was recognized by my being listed as Assistant Editor, and in 1959 Ray Adie was added to the Advisory Committee, joining me as an Assistant Editor a year later. In 1961 Gerald Seligman, John Glen, Ray Adie and Doris Johnson are listed as 'Editors' and the old 'Editorial Advisory Board' was dropped. We had a duplicated list of style details which we worked to, and we kept to the rule that spelling in a paper had to be consistent but could be English, American or Canadian usage.

Although the Journal was founded by an essentially British society, it had from its early days printed articles by glaciologists from many countries while the editing and editorial advice was entirely by Britons. In 1962 the Council 


\section{The \\ Journal of Glaciology}

\begin{tabular}{lll} 
VOL. I JANUARY 1947 & No. I \\
\hline
\end{tabular}

\section{CONTENTS}

\begin{tabular}{|c|c|}
\hline THE JOURNAL OF GLACIOLOGY & $\begin{array}{l}\text { page } \\
\text { page }\end{array}$ \\
\hline BRITISH GLACIOLOGICAL SOCIETY & page 5 \\
\hline TRANSACTIONS OF THE FORMER A.S.S.I. & page 5 \\
\hline \multicolumn{2}{|l|}{ MEETINGS : } \\
\hline Investigations on Ice during the War. By R. Moss & page \\
\hline By A. R. Glen & page \\
\hline Extrusion Flow in Glaciers. By G. Seligman & page 12 \\
\hline F. A. Wade's Antarctic Researches. By W. L. S. FLemING & page 23 \\
\hline SNOW SURVEY OF THE BRITISH ISLES & page 32 \\
\hline AVALANCHE RESEARCH & page 32 \\
\hline SCOTTISH SNOW CONDITIONS & \\
\hline ICE AND AERIAL EROSION & page 33 \\
\hline GLACIER FLOW AND GRAIN GROWTH & page 34 \\
\hline THE RONDANE, NORWAY & page 34 \\
\hline "CRYOLOGY" & page 35 \\
\hline MEETING OF THE I.U.G.G. & page 35 \\
\hline CANADIAN SNOW RESEARCH & page 36 \\
\hline FIXING SNOWFLAKES & \\
\hline A NEW METHOD OF GLACIER EXAMINATION & page 37 \\
\hline CROSS SECTION OF GLACIATED VALLEYS. By W. V. LEwIS & page 37 \\
\hline CORRESPONDENCE & \\
\hline NOTES & \\
\hline GLACIOLOGICAL LITERATURE & page 40 \\
\hline
\end{tabular}

\section{Published by \\ THE BRITISH GLACIOLOGICAL SOCIETY c/o The Royal Geographical Society, Kensington Gore, London, S.W.7}

Fig. 1. The contents list of No. 1 of the Journal of Glaciology.

began to move away from this by appointing 'Editorial Advisors' from around the world. A footnote on the reverse cover of No. 33 says 'The Council have appointed these members of the Society as Editorial Advisors, in recognition of the help they give to the Editors.' The list consists of Albert Bauer (France), Richard Finsterwalder (Germany), Børge Fristrup (Denmark), Claude J. Lorius (France), Mark F. Meier (UK), John F. Nye (UK), Brian B. Roberts (UK) and Valter Schytt (Sweden). Among the help given by these was the provision of French and German translations of the abstracts of all papers. These Editorial Advisors thus represented a move away from an all-British run journal and show appreciation of the fact that the Journal served the needs of the international glaciological community.

A similar thing was happening to the membership of the Society: more members were joining from a number of countries, so the Council had to recognize that it was no longer primarily a British society. They thus dropped the word 'British' from its title in 1962, and after some suggestion that calling it 'the Glaciological Society' might be seen as the British assuming their society needed no national title (see the Royal Society!), ten years later they added 'International' to its title to form the International Glaciological Society we know today. The Journal was also 
growing in size and in 1962, after 15 years (30 issues in three volumes), we began publishing three issues each year of a volume consisting of six issues. However, the growth in the number of papers meant that this only lasted for 6 years and in 1968 Volume 7 had only three issues and a multiissue volume has been published each year ever since.

The next major change came with the decision to publish a special volume consisting of just one issue to contain papers originating from a conference organized by the Society. The first of these was in 1975 when Volume 15 contained papers from a conference on Remote Sensing in Glaciology, and the following year Volume 16 did the same for a conference on Thermal Regime of Ice Sheets. This pattern continued for a number of years up to 1980, with two volumes being published each year, one containing the regular three issues and the other the papers from a conference (except that there were two consecutive conferences published as two separate volumes in 1979). This function was later taken over by placing these conference volumes in their own journal, Annals of Glaciology, the first of which was published in 1980.

In 1968 Gerald Seligman ceased to be listed among the Editors and his name appeared in the list of Editorial Advisors and I took over his role as the editor allocating papers among us and coordinating the process. In 1976 David Homer was listed as an Assistant Editor, to be raised to the full status of Editor the following year. Throughout this period the Journal was produced by a printer employed by the Society for this purpose, but modern techniques were making it possible for the setting of journals to be removed from the printers and done in-house on electronic typewriters or word processors, and in the late 1970s and early 1980s the Council of the Society discussed how the Society might benefit from these changes. From 1984 the Journal changed, with the Society doing the setting work in-house in Cambridge and changing format to the International Standard A4 size, a format which, with improvements in the typeface, continues to this day. (Annals of Glaciology was produced in this way from the start.) This seems a reasonable point at which to stop an 'early history' as the whole process of editing and production changed then and it became possible to have a Chief Editor in any country of the world.

The Journal today is a much larger production than in the earlier years; there are many more papers per year and they are on average much longer than those in the first volume, but the subject coverage and the interest remains much the same, and, as we have seen, some features, like an 'Instruments and Methods' designation for some papers, remain from the first to the current volume. I think the aims of the first Advisory Board and the hopes expressed by the eminent writers of the first forewords are still being amply met. 